\title{
PLACING HIS THOUGHTS IN PERSPECTIVE: A SURVEY OF WORKS ON FAZLUR RAHMAN
}

\author{
Navin G. Haider Ali \\ Pakistan Study Centre, \\ University of Karachi
}

\begin{abstract}
Fazlur Rahman, the renowned Muslim thinker who lived in the second half of the twentieth century, impacted young scholars and students of Islam of his generation and those of the next, both from the Muslim world and the West. Many research scholars and thinkers who have written on Islam have been highly impressed by his methodology of interpreting the Qur'ān which is why there has been so much focus on this aspect of his work in the context of his contribution to Islamic scholarship. However, while one is drawn to examine this aspect of his work, there are other equally interesting aspect of his thoughts that have not been given the equal treatment, such as a study of the evolution of his thought over various decades of his life and career etc. The present article is meant to present a critical survey of the works of Islamicists on Fazlur Rahman's thought and contribution.
\end{abstract}

Keywords: Fazlur Rahman, methodology, Islamicists, Qur'ān, interpretation

\section{Methodology for the Interpretation of the Qur'an}

Fazlur Rahman's major contribution to Islamic scholarship is considered to be his presentation of a methodology for the interpretation of the Qur'ān to which different writers have given different names. He himself called it the "Double Movement Method." This method keeps the Qur'ānic text in its historical context, extracts general moral values, evaluates the present society on the basis of these extracted values, and suggests ways and the changes necessary to make these values relevant to the present and/or the present relevant to the values. This method of Qur'ānic interpretation proposed by Fazlur Rahman was so important and engaging that most Islamicists of the Muslim World and of the West could not remain indifferent-they either appreciated it or debunked it.

Mary Catherine Jesse places Fazlur Rahman in the category of modern Muslim intellectuals. She examines his thoughts from the perspective of the role of reason in modern Muslim faith. The author's hypothesis is that Fazlur Rahman made a significant contribution to the debate regarding the place of reason in Islam by adopting an approach that she identifies as 'ethical rationalism.' Jesse opines that for

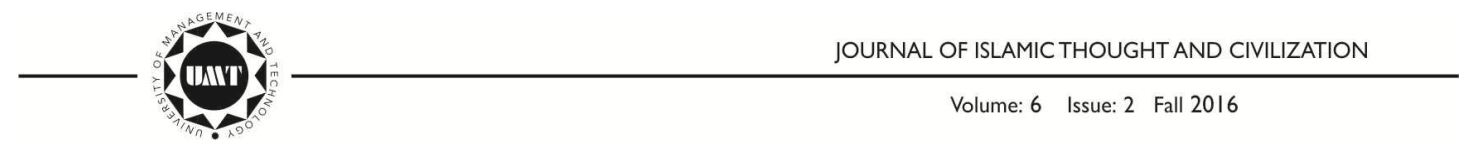




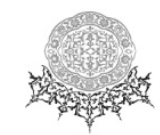

Fazlur Rahman Islamic modernism meant a systematic interpretation of the Qur'ān which would meet the demands of both ethics and modern day rationality. ${ }^{1}$

If Jesse considers Fazlur Rahman's method ethical-rational, one of Fazlur Rahman's students and a formidable scholar in her own right, Tamara Sonn, places Fazlur Rahman's method in the category of historicism. In her article she explains indetail Fazlur Rahman's methodology and explains why he thought that there was a need for a new method of interpreting the text. The significant thing about Sonn's article is that she tries to place Fazlur Rahman's methodology in the contemporary context by comparing it with other contemporary methodologies of Qur'ānic interpretation and by highlighting the importance of his methodology. She explains his methodology in the context of a "modern thought called "historicism" in the West. ${ }^{2}$ According to her, the origin of Fazlur Rahman's method was in European history and, along with him, a couple of other Muslim modernists, the Algerian scholar Muhammed Arkoun (1928-2010) and the Moroccan scholar 'Abd Allah (SWT) al-'Arwi (1933-), also followed this method. However, she distinguishes Fazlur Rahman from them, "Both use Western historical terminology: Muhammad Arkūn uses the term al-tarikhiyya, whereas al-'Arwi uses al-tarikhaniyya. Because of their use of this terminology, there is a tendency to view their methodology itself as Western. But Fazlur Rahman's Islamic methodology is historicist in a totally Islamic idiom." 3

For her, Fazlur Rahman's work occupied an important place because he was not attempting to explain Islam "as it existed in some other historical context, but to devise away to articulate those principles which mark any society as Islamic." 4

Another student of Fazlur Rahman, Frederick M. Denny, describes Fazlur Rahman's efforts as expressing Islamic Mindedness. Denny based his argument on 'how far rational reflection and analysis should go unfettered by divinely revealed truth as found in the Qur'ān or described through the medium of Prophetic Hadith?'5 According to Denny, Fazlur Rahman's approach 'is based on prior conviction about "first principles" that are rooted in faith, ${ }^{6}$ faith not just as a belief system but as a commitment of will and moral vision.

\footnotetext{
${ }^{1}$ Mary Catherine Jesse, “A Modern Muslim Intellectual: The Thought of Fazlur Rahman with Special Reference to Reason,” (M.A Dissertation, University of Regina, 1991), i-ii.

${ }^{2}$ Tamara Sonn, "Fazlur Rahman's Islamic Methodology," in The Muslim World, Vol. LXXXI, No.3-4 (1991): 227.

${ }^{3}$ Ibid.

${ }^{4}$ Ibid., 229.

${ }^{5}$ Frederick M. Denny, "Fazlur Rahman: Muslim Intellectual," in The Muslim World, Vol. LXXIX, No.2 (1989): 91.

${ }^{6}$ Ibid.

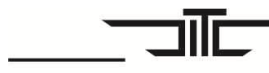

JOURNAL OF ISLAMICTHOUGHT AND CIVILIZATION 
However, taking cue from Fazlur Rahman himself, Denny tries to define what 'Islamic-minded"7 actually meant to Fazlur Rahman, how he showed himself to be an Islamic-minded intellectual, and how this Islamic-mindedness actually served as a regulative principle in his intellectualism. According to Denny, Fazlur Rahman differentiated between 'higher religio-moral cognition and other forms of intellectual cognitions.' ${ }^{8} \mathrm{He}$ then goes on to say that it was on these grounds that 'Fazlur Rahman's position was that the Qur'ān is indeed the charter for authentic Muslim faith, thought and action, as well as the empowering presence for the great moral struggle that translates religious affections into carefully considered deeds of justice and compassion.' 9

Another person who studied Fazlur Rahman was Ahmar Rasyid, who took two legal issues from Fazlur Rahman's writings, i.e., zakat (alms) and riba (usury), and tried to critically evaluate the strengths and weaknesses of Fazlur Rahman's method. ${ }^{10}$ This case-based study provides the reader an understanding of how Fazlur Rahman practically applied his method to two specific legal issues written in the Qur'ān.

However, some contemporary scholars in the field have criticized Fazlur Rahman's method rather harshly. One such scholar is Waheed Hussain. Two of his articles ${ }^{11}$ discuss almost the same subject and use more or less the same arguments to support his thesis. According to Hussain, "Islamic modernism contends that Muslimsshould revise their conventional understanding of the requirements of their religion in the light of fresh interpretations of authoritative texts." ${ }^{12}$ However, according to him Islamic modernists have failed to distinguish between "the arguments that the social scientists make about the requirements of a religion and the arguments that participants in a religion should accept." ${ }^{13}$ Hussain takes Fazlur Rahman as a case in point, as an Islamic modernist, to critically argue his thesis. He maintains that, "for a participant, arguments must ultimately appeal to the nature of the authority that gives him a reason to follow the rules of a practice, but for a social

\footnotetext{
${ }^{7}$ While discussing the bone of contention between the philosophers and theologians, Fazlur Rahman argues that the philosophers were neither bold enough nor Islamic-minded.

${ }^{8}$ Denny, Fazlur Rahman: Muslim Intellectual, 93.

${ }^{9}$ Ibid., 100.

${ }^{10}$ Ahmar Rasyid, “Some Qur'ānic Legal Texts in the Context of Fazlur Rahman's Hermeneutical Method,” (M.A Thesis: McGill University, 1994), 1.

${ }^{11}$ Waheed Hussain, "A Philosophical Critique of Fazlur Rahman's Islam and Modernity," in Harvard Middle Eastern and Islamic-Review Vol.6 (2000-2001), and the, "Interpreting the Tradition: The Modernist Argument and the Source of Islam," in The American Journal of Islamic Social Science, Vol.18, No.1 (2001)

${ }^{12}$ Waheed Hussain, "Interpreting the Tradition: The Modernist Argument and the Source of Islam," op. cit. 1 .

${ }^{13}$ Ibid.
}

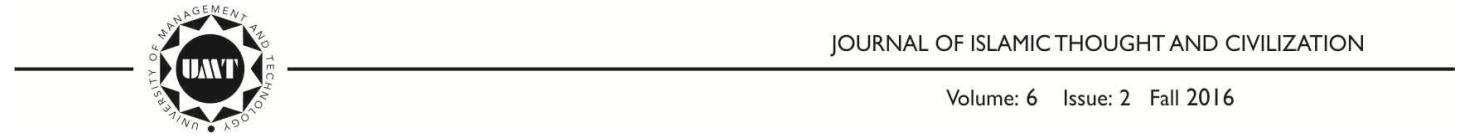




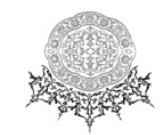

scientist, arguments must ultimately appeal to his explanatory interests in the practices." 14

He explains his point through a very complicated argument in which he cites the game of chess as an example. Hussain believes there is a difference between manuals that lay down the general rules and regulations for those playing chess and for those who merely wish to follow the game as observers. Hussain argues that if as a Muslim modernist Fazlur Rahman wants Muslims to reinterpret the text to capture its original, synthetic meaning that has been lost in the plethora of interpretations by ulama in historical Islam, and if Fazlur Rahman suggests a method of his own for capturing theoriginal meaning of the text, then it must be believed that this method was 'aimed at Muslims and not at social scientists.' 15

Another major fault that Hussain finds with Fazlur Rahman's method is that itfocuses on convincing Muslims that they should adopt or continue certain practicesbecause other Muslims consider them right. Moreover, the method does not 'showparticipants in Islamic practice why they should adopt an interpretive manual which focuses primarily on the Qur'ān.' He then goes on to say that Muslims today and those inthe past may strongly believe that the Qur'ān can provide answers to all issues. However, unless Fazlur Rahman argues that this is true and that the Quran actually does provide answers to all issues, "Muslims today cannot take the mere fact that other Muslims believed — and continue to believe- that it does, as a reason for following the rules contained in it." 16

Hence, after critically evaluating Fazlur Rahman's book Islam and Modernity onthe basis of the above mentioned arguments, Hussain concludes that, "Since Rahman does not offer arguments of this kind in support of his interpretive method in Islam and Modernity, I think that he ultimately does not make a compelling case for his view."17

While Hussain finds fault with Fazlur Rahman's method, and argues that it does not make a compelling case for the participants in faith to follow his methodology, Kenneth Cragg has other reasons to criticize Fazlur Rahman. ${ }^{18}$ Cragg focuses ontwo of Fazlur Rahman's books to substantiate his views, i.e., The Major Themes of the Qur'ān and Islam and Modernity. Cragg believes the first book argues that 'the Qur'ân is the command of God for man,' a command which requires obedience in action. ${ }^{19}$ The second book, Islam and Modernity, explains Fazlur

\footnotetext{
${ }^{14}$ Ibid., 13-4.

${ }^{15}$ Ibid., 10.

${ }^{16}$ Ibid.

${ }^{17}$ Waheed Hussain, “A Philosophical Critique of Fazlur Rahman's Islam and Modernity,” 78.

${ }^{18}$ Kenneth Cragg, "Fazlur Rahman of Karachi and Chicago," in The Pen and The Faith: Eight Modern Muslim Writers and the Qur'ān (London: George Allen \&Unwin, 1985)

${ }^{19}$ Ibid., 92.
}

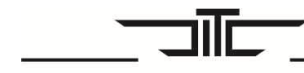

JOURNAL OF ISLAMIC THOUGHT AND CIVILIZATION 
Rahman's methodology of Qur'ānic interpretation and its application through his suggested system of education. Cragg states, "Fazlur Rahman has been deeply committed to what must be seen as the faith obligationin the overlap of generationsan overlap which has never been more critical." ${ }^{20}$ And all of Fazlur Rahman's impulses in Qur'ānic scholarship derive from this urgency. Cragg believes that Fazlur Rahman is aware of the deep dichotomy in Muslim education, between traditional studies, as in Al-Azhar and Deoband, and the modern sciences with their practical bearing and their instinctive empiricism and man-centred view. But he finds that "all efforts, after a genuine integration between these patterns, have so far beenlargely unfruitful.", 21

Cragg's main concern is the viability of a religion based totally on "Command'; 'whether a theology so exclusively given to "Command" can suffice either to guide contemporary society or to instill- not to say merit - the vital taqwa of man,' because 'the world in which this definitive and concrete taqwa has to be commended...is increasingly beset by perplexities about the grounds and the claims of such obedience." 22

One important factor in the context of 'Command,' according to Cragg, is technology. He states, "Technology tends to reduce the 'commandedness' of man because it seems to leave so much in his hands... There seems to be a permissiveness about our scientific experience_-not in the familiar way that 'anything goes' but in a more subtle sense that things eventuate not by reference to obligation but by the impact of feasibility." ${ }^{23}$ Where taqwa is concerned, Cragg maintains that a cause for concern is that, "we have so sadly failed to enforce the disciplines that taqwa involves." He then raises the question "whether the failing taqwa truly has either the clue or the capacity? Ifnot, have we a theology of, or for, the society today?"24

This is where Cragg feels that the modernists have an important role to play,

It is just here, perhaps, that Fazlur Rahman and others with him in Islam need both moreperception and more compassion about secularity and secularists. It is easy to reproach it and them, to align it with 'atheism,' and to associate it with 'fasad on the earth' the corruption in the dunya, or lower world, from which Islam must keep immune.' The question, however, is 'Will such a faith interpretation avail if it is confined to a theology of command that does not reckon with the autonomy which, without restrains except our own, we seem to possess? ? $^{25}$

\footnotetext{
${ }^{20}$ Ibid.

${ }^{21}$ Ibid., 93.

${ }^{22}$ Ibid., 106.

${ }^{23}$ Ibid.

${ }^{24}$ Ibid.

${ }^{25}$ Ibid.
}

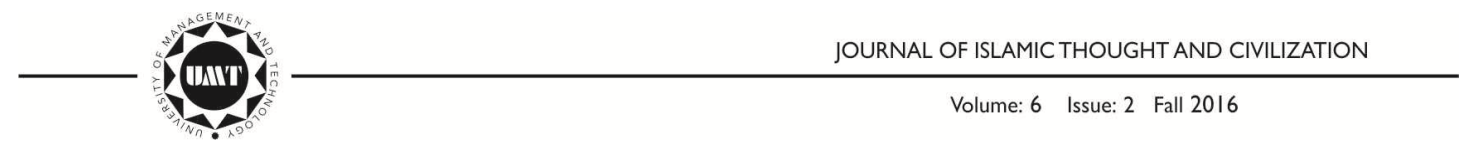




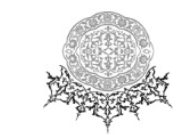

Cragg acknowledges Fazlur Rahman's contribution, but he questions his insistence on absolute reliance on the 'Command of the God' to resolve all matters. He opines that,

Fazlur Rahman aptly describes his overall purpose as not that of 'saving religion from modernity, but of saving modern man through religion.' In his critique of the method of the Qur'ān's interpretation, his insistence that revelation intends obedience not information, and his anchoring of personal and social well-being in the active consciousness of divine Lordship, he has gone far to serve that purpose. His rejection of what he sees as impeding it is trenchant and courageous. He finds neofundamentalism as only emotionally bracing Islam while failing it mentally. He deplores what he calls Islam's 'pitiable subjugation of religion to politics' rather than genuine Islamic values controlling politics. He can understand, for example, why Ataturk was forced to opt for secularism, and why the young today, unless captured by traditionalism, are so readily at risk to the same option. All this is well taken. But the issue remains how the 'Command of God' in itself can be regulative for man, while the question of God Himself has become, in one way, so negligible and, in another, so elusive for contemporary society. ${ }^{26}$

Adding to the debate on the strength and weakness of Fazlur Rahman's method, Donald Lee Berry considers his method a good example and suggests Christianity take advantage of this to overcome the problems of modernity. In his $\mathrm{PhD}$ dissertation, ${ }^{27}$ he discusses the response of Islam to modernity with reference to Fazlur Rahman and argues that the issue of modernity was not specific to Islam as a religion but affected all living religions in the modern age. He argues that Christianity can learn from the experience of Islam through Fazlur Rahman's writings and that in return Christianity can help other religions to respond to the ever-increasing issue of modernity. In Berry's words, "The dual focus of this dissertation will be to discover an avenue by which one can celebrate one's heritage while addressing the common dilemma of modernity and to reveal a response to modernity through the eyes of an influential Muslim scholar, Fazlur Rahman."28

Yet another scholar, Ebrahim Moosa, in his 30-page introduction to Fazlur Rahman's posthumous book, Revival and Reform in Islam, ${ }^{29}$ which he edited, gives a critical evaluation of Fazlur Rahman's Qur'ānic hermeneutics or his double movement method. Moosa traces the impact that Muslim and Western scholars have had on the development of Fazlur Rahman's method and finds a deep Western impact on Rahman's method. He also highlights some of the major shortcomings in his

${ }^{26}$ Ibid., 101.

${ }^{27}$ Donald Lee Berry, "The Thought of Fazlur Rahman as an Islamic Response to Modernity," which was published as a book with the title Islam and Modernity through the Writings of Islamic Modernist Fazlur Rahman (Lewiston, N.Y: Edwin Mellen Press, 2003)

${ }^{28}$ Ibid., 2.

${ }^{29}$ Fazlur Rahman, Revival and Reform in Islam: A Study of Islamic Fundamentalism, (ed.) Ebrahim Moosa (Oxford: One world Publications, 2000)

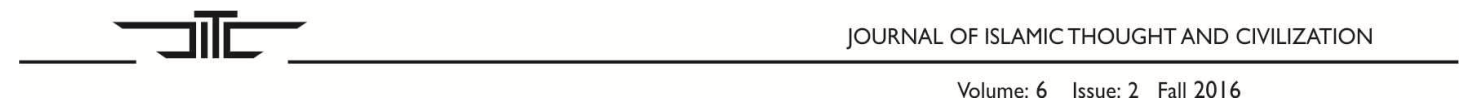


method. For Moosa, it is not just the current political and economic conditions of most Muslims that cause them to reject the modernist approach but also shortcomings in the modernists' methods. ${ }^{30}$

\section{Between Tradition and Modernity}

Another area of Fazlur Rahman's thought that has been critically evaluated is his views on historical Islam, or Islamic tradition as it evolved in history, particularly afterthe earliest period of Islamic history which ended with the Prophet $(S A W)$ and the four Rashidun Caliphs $(R A)$. Fazlur Rahman's general stand on this is that everything in history should be evaluated strictly on the basis of the Qur'ān, and only those traditions found compatible with the message of the Qur'ān should be taken as Islamic while the rest should berejected outright. To Fazlur Rahman, unfortunately, most historical Islam is in contradiction with the message of the Qur'ān. ${ }^{31}$

This was a very strong position vis-a-vis traditional Islam. Hence Fazlur Rahman's position was both fiercely defended and criticized. In one of his articles, ${ }^{32}$ Ibrahim Ozdemir discusses Fazlur Rahman's concept of Islamic tradition (which Fazlur Rahman prefers to call Muslim tradition) and concludes that, contrary to what is commonly perceived, Fazlur Rahman was not against tradition as such. His criticism and questioning of this tradition was in order to demarcate the tradition's Islamicity from its historical aspects, "so that when he reaches a new solution for a given contemporary problem, he can justifiably claim that his new solution may be in conflict with the tradition's historicity but not with its Islamicity. Therefore, one should not say that Rahman is ignoring or rejecting the tradition." 33

S. Parvez Manzoor, ${ }^{34}$ another writer who deals with the same issue of Islamictradition and Fazlur Rahman's thought, after critically evaluating his role in bridging thegap between modernity and tradition which he equates with transcendence and immanence, says, "The paradox of Fazlur Rahman's scholarship is that while he stood firm in his commitment to the historicity of the text, he readily abandoned its interpretations by tradition. In saving text, he had to damn the history of its reading." 35

Another angle from which modernists' views on history and/or tradition is evaluated is intheir dealing with the subject of Islamic revival and reform which is often considered tohave its origins in the period immediately following the Prophet's $(S A W)$ death. Alparslan Acikgenc ${ }^{36}$ says, "The history of Islamic revival and reform can be extended back to even the earliest times of Islam so that one may be justified to reasonably claim its roots to be imbedded in the very events that took place immediately upon the Prophet's $(S A W)$ death."37 In his opinion, Fazlur Rahman spent

\footnotetext{
${ }^{30}$ Ibid., 25-6.
}

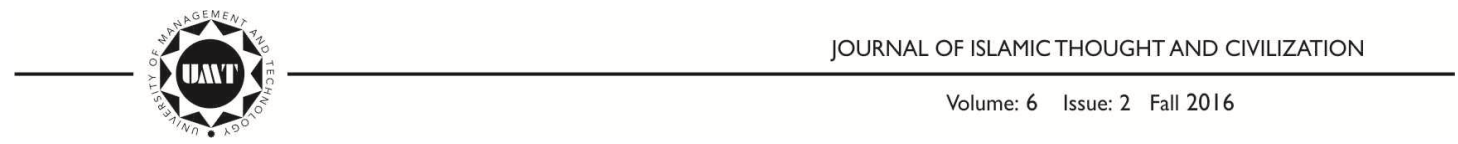




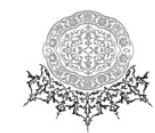

a considerable part of his life in "the study of this phenomenon; and thus deserves more than any other in the field to be called the "thinker of revival and reform.", 38

In his previously mentioned work Moosa also explains why the subject Revival and Reform in Islam was so important to Fazlur Rahman that towards the end of his lifehe was writing on this topic. Moosa regrets that Fazlur Rahman did not live long enough to bring the phenomenon of Revival and Reform and the personalities carrying this agenda to modern times. ${ }^{39}$

Another important aspect of Fazlur Rahman's modernist project is his engagement with education; because, with respect to the "faith obligation in the overlap of generations," has always remained central for Muslim thinkers. Hence pioneers of Muslim modernism like Sir Syed Ahmad Khan (1817-1898) and Muhammad Abduh (18491905) gave education utmost importance. During the 1970s, the process of Islamic education was overwhelmed by the concept of Islamization of knowledge, especially in the writings of Ismail Raji al-Faruqi (1921-1986) and Syed Muhammad Naquib alAttas (b.1931); the former was Fazlur Rahman's contemporary and the latter was one of his students.

The concept of Islamization in Fazlur Rahman's writings is not very clear. Thus, when comparing Fazlur Rahman with other Islamic thinkers, writers have come to different conclusions. For example, Cragg concludes,

He wants to Islamise all the fields of education, especially the higher levels, where the main damage is done, either by the neutralizing effects of the physical sciences or by the subjectivism of social sciences... Any hope in it requires a clear obedience to the Qur'ān, investing factual knowledge with sure Islamic values...It is the scope and tension of this aspect of modernity which imbue his whole handling of the Qur'ān. ${ }^{41}$

${ }^{31}$ Fazlur Rahman, "Personal Statement," in The Courage of Conviction, ed. Phillip L. Berman (New York: 1985), 155.

${ }^{32}$ Ibrahim Ozdemir, "The Concept of Islamic Tradition in Fazlur Rahman's Thought," in The American Journal of Islamic Social Sciences, Vol.9, No.2 (Summer 1992).

${ }^{33}$ Ibid., 259.

${ }^{34}$ S. Parvez Manzoor, "Damning History but Saving the Text: Fazlur Rahman between Tradition and Modernity," Islamica 2, no. 4 (1998): 4l-4.

${ }^{35}$ Ibid., 44.

${ }^{36}$ Alparslan Acikgenc, “The Thinker of Islamic Revival and Reform: Fazlur Rahman's Life and Thought (1919-1988)," in The Journal of Islamic Research, Vol 4, No 4 (1990): 232-48.

${ }^{37}$ Ibid., 232.

${ }^{38}$ Ibid.

${ }^{39}$ Fazlur Rahman, Revival and Reform in Islam: A Study of Islamic Fundamentalism, (ed.) Ebrahim Moosa, 8.

${ }^{40}$ Kenneth Cragg, "Fazlur Rahman of Karachi and Chicago," in The Pen and The Faith: Eight Modern Muslim Writers and the Qur'ān, 92.

${ }^{41}$ Ibid., 93.

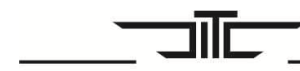

JOURNAL OF ISLAMICTHOUGHT AND CIVILIZATION 
Contrary to Cragg, Yasien Mohamed ${ }^{42}$ does not see much enthusiasm in Fazlur Rahman for the project of the project of Islamization of all the traditional Islamic subjects, as conceived byFaruqi. In his opinion,

Fazlur Rahman was neither a proponent nor an opponent of Islamization, but he was critical of the contemporary approach to Islamization. Ismail Faruqi's Islamization of Knowledge is a critical, revivalistic response to modernity. Fazlur Rahman's Islam and Modernity is a critical, modernist response to both the modern and Islamic disciplines. $^{43}$

Continuing his argument, he maintains that what Fazlur Rahman opposed was notIslamization per se but the way Faruqi approached this concept which did not permit a 'critique of an Islamic legacy that is historically conditioned.' On the other hand, according to Mohamed, Fazlur Rahman believed in "the elaboration of an Islamic metaphysics on the basis of the Qur'ān is imperative before the goal of Islamization can be achieved. That is to say, an Islamic worldview must first be attempted if the intellectual disciplines are to cohere on the basis of Islam.",44

Winding up the debate on Faruqi versus Rahman, Mohamed concludes that, in contemporary times Faruqi seems to have met the needs of the Muslims by offering some 'practical solutions to the intellectual dilemma faced by western educated Muslims.' However,

Although Rahman's impact is less widespread than Faruqi's, he has left us with a wealth of scholarly literature. His book Islam, for example, is used as a prescribed textbook at many universities. Furthermore, he has had a lasting impact on serious thinkers of Islam, such as the Ijmalis. ${ }^{45}$ It is to be expected that Rahman's writings will no doubt make a great impact on the future generations of Muslims, as their lifestyle becomes an integral part of modernity. ${ }^{46}$

Another writer, Muhammad Shafiq, discusses the same topic but along with Fazlur Rahman and Faruqi he includes S. Hussein Nasr in this debate of Islamization. In his article, ${ }^{47}$ he tries to find points of convergence and disagreement between these three thinkers on this subject. Shafiq believes that, "al-Faruqi, Nasr, and Fazlur

${ }^{42}$ Yasien Mohamed, "Islamization of Knowledge: A Comparative Analysis of Faruqi and Rahman," in Muslim Education Quarterly, Vol.11, No.1 (1993): 27-40.

${ }^{43}$ Ibid., 27-8.

${ }^{44}$ Ibid., 30.

${ }^{45}$ Ibid., 34 Explaining who he means by Ijmalis, Yasien states that, 'The Ijmali thesis is that disciplines evolve within a particular worldview; and the social sciences emerged out of the Postenlightenment materialistic worldview; and these western paradigms cannot be stripped of their values and metaphysical assumptions. To Islamize these disciplines is irrelevant to Muslim societies.'He includes, Ziauddin Sardar, M.W. Davies and Parvez Manzoor in this category of Ijmalis.

${ }^{46}$ Ibid., 31.

${ }^{47}$ Muhammad Shafiq, "Islamization of Knowledge: Philosophy and Methodology and Analysis of the views and ideas of Ismail Raji al-Faruqi, S. Hussein Nasr and Fazlur Rahman," in Hamdard Islamicus, Vol. XVIII, No.3 (1995): 63-75.

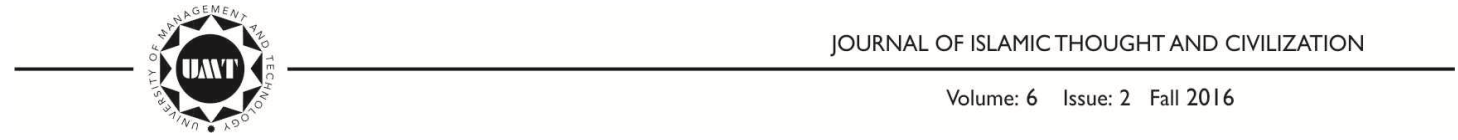


Rahman, all agreed that modern knowledge is not neutral, but instead of its being sacred and beneficent in general, it is dangerously leading humanity towards a disaster."48

However, according to Shafiq, although Fazlur Rahman does not discard western knowledge altogether and finds some good values in it, al-Faruqi's method seems more applicable since he also suggests some practical steps for the application of his method. ${ }^{49}$

Yet another article covering the topic of Islamization with special reference to al-Attas and Fazlur Rahman is the one written by Wan Mohd Nor Wan Daud. ${ }^{50} \mathrm{He}$ begins by arguing that al-Attas was the initiator of the idea of Islamization of knowledge; in fact, years before al-Faruqi synthetically and systematically organized this idea in the 1970s, it was al-Attas who introduced it in 1966. Daud discusses alAttas' idea of Islamization of knowledge at some length; in comparison, the space given to Fazlur Rahman's idea is less. It is evident from his arguments that Daud himself was a follower of al-Attas' ideas which seem to fall in the category of Muslim traditionalists. Moreover, it is also evident from the article that Daud's understanding of Fazlur Rahman's ideas is weak as compared to his understanding of the ideas of alAttas; hence, there is more criticism and less appreciation of Fazlur Rahman's ideas.

Daud defines al-Attas' Project as,

$[\mathrm{H}]$ aving the inner vitality and traditional legitimacy to help Muslims benefit from their rich and living spiritual and intellectual heritage and resources, and to guide not only their own intellectuals and compatriots, but also the large part of serious minded people from other religions, in confronting the insidious and morally crippling effects of global secularization as a philosophical program and a way of life. ${ }^{51}$

However, with regard to Islam and Modernity, by Fazlur Rahman, he says that Fazlur Rahman commented rather extensively on efforts to 'Islamize' the education of Muslims - that is, to inform it with certain key concepts of Islam.' He further says that "The whole of Islam and Modernity is full of statements indicating that nobody in thehistory of Islam has attempted such an endeavour, with the exception of Iqbal." ${ }^{, 52}$ Daud argues that Fazlur Rahman's belief that 'the theologians, jurists and sufis of medieval Islam were not able to conform to the spirit of the Qur'ān,' is presumptuous because the Qur'ān itself does not expect every one of its teachingsto be completely

\footnotetext{
${ }^{48}$ Ibid., 65.

${ }^{49}$ Ibid., 73.

${ }^{50}$ Wah Mohd Nor Wan Daud, "Islamization of Contemporary Knowledge: A Brief
} Comparison between Al-Attas and Fazlur Rahman," in Al-Shajarah (Journal of the International Institute of Islamic Thought and Civilization), Vol.2, No. 1 (1997): 253-61.

${ }^{51}$ Ibid., 2.

${ }^{52}$ Ibid., 13.

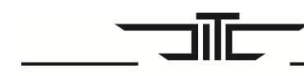

JOURNAL OF ISLAMIC THOUGHT AND CIVILIZATION 
and perfectlyunderstood by its readers, even by scholars and the like. ${ }^{53}$ However, the researcher found contradictions in Daud's mostly judgmental statements about Fazlur Rahman.

Recently, Farid Panjwani has written an exhaustive article on Fazlur Rahman's contributions to education. ${ }^{54}$ Going through the historical background of the issue of Islamic education in the context of modern Western educational system with its own merits and demerits, Panjwani not only places Fazlur Rahman's educational project inperspective but also critically evaluates its shortcomings. In the final analysis, he says,

Perhaps his most important legacy is the boldness with which he made proposals for reforms. Modernity was an opportunity and a challenge for him. Many of his followers, particularly those working on extremely sensitive matters like gender and sexuality, and who wished to engage with modernity as a challenge and an opportunity, draw upon his work. Weaknesses in his approach are not confined to him alone. They are endemic to the entire modernist tradition. They are accentuated in his case because, unlike many other reformists, Fazlur Rahman wanted to remain a thoroughgoing scholar; herein lay the tension between Fazlur Rahman as a scholar and Fazlur Rahman as a religious reformer-it is indeed a tension between history and hope. ${ }^{55}$

\section{The Thinker Evolved}

Having briefly surveyed different writers' views and responses with respect to Fazlur Rahman's thought and viewpoint, let us now turn to some articles and studies that give anoverview of Fazlur Rahman's life and thought. A study of these articles is important because they divide Fazlur Rahman's academic career into specific phases thereby giving us an insight into the evolution of his thought. In his article entitled "The Legacy of Fazlur Rahman," i.e., philosophical-theological, moral-ethical, and religious-communal. ${ }^{57}$ However, he makes it very clearthat all three aspects of his life-as writer, activist or teachercomplement and supporteach other. He further says, "Just as there was no disjunction between Rahman's thought, life, and works, so there is none among the three aspects of his legacy we examine here. For Fazlur Rahman, the scholarly, the moral-religious, and the legal-communal dimensions were all of a part." ${ }^{, 58}$

\footnotetext{
${ }^{53}$ Ibid., 14.

${ }^{54}$ Farid Panjwani, "Fazlur Rahman and the Search for Authentic Islamic Education: A Critical Appreciation," in Curriculum Inquiry Vol.42, No.1 (2012): 33-55.

${ }^{55}$ Ibid., 50.

${ }^{56}$ Fredrik Mathewson Denny, "Legacy of Fazlur Rahman," in The Muslims of America (ed.) Y.Y. Haddad (New York: Oxford University Press 1991), 96-108.

${ }^{57}$ Ibid., 96.

${ }^{58}$ Ibid.
}

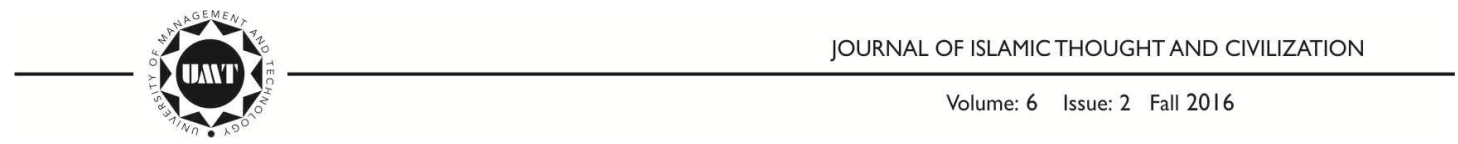


However, along with this thematic division, Denny also divides Fazlur Rahman's career into three periods; the first of these, the 'early period' from the years of his studies to his jobs in Durham and McGill, according to him, is "focused mainly on philosophy and theology as known through classical Islamic sources." 59 The second period is the 'Pakistani period,' which "saw continued foundational thinking but with an agenda dictated by Rahman's leadership role in the development of sound Islamic Studies curricula for the young country's religious leaders." ${ }^{60}$ The third is the 'Chicago Period,' when "Rahman published a number of major articles and four books, whose titles are avertable memorandum of the complete range of his career." ${ }^{, 61}$

Denny knew too well that, like the above mentioned three themes, these periodical categories of Fazlur Rahman's life were superficial and often overlapping. However, he pointedly stated that while he would 'draw on works from all periods of his career, 'he would focus on the latter years of his life, the Chicago period. This is because he believed it was during this period that "all three dimensions-the philosophical-theological, moral-ethical, and religious-communal-were fully integrated in Rahman's mature and vigorously Qur'ānically based vision of authentic Islam for this age." 62

Acikgenc also divides Fazlur Rahman's career into three periods: 1) The crisis period, which covers the time of acquiring education until his early teaching career at Durham; 2) The synthesis period, beginning from 1958, when he began teaching at McGill, until his resignation in 1968 from the directorship of the Central Institute of Islamic Research; 3) The resolution period, which covers his teaching career at the University of Chicago (1969-1988). ${ }^{63}$

Aliya Iqbal, on the other hand, focuses only on Fazlur Rahman's career in Pakistan. In her B.A. (Honours') dissertation entitled, "Never Quite at Home: The Mystery of Fazlur Rahman's Anonymity in Pakistan," 64 she tries to satisfy her personal curiosity as a Pakistani about Fazlur Rahman. This thesis is in essence a personal search of an upper class, educated and Westernized young Pakistani girl who at the age of eighteen while studying the Qur'ān at Cornel University learns of a Pakistani Islamicist scholar of international fame and acclaim, and is astonished at this scholar's anonymity at home especially among the elite class of her country on whose behalf Fazlur Rahman supposedly spoke during his stay in the US in the decade of the 1960s. Through this thesis she tries to discover why, even in the upper

${ }^{59}$ Ibid., 97.

${ }^{60}$ Ibid.

${ }^{61}$ Ibid., 98.

${ }^{62}$ Ibid.

${ }^{63}$ Alparslan Acikgenc, op. cit., 239.

${ }^{64}$ Aliya Iqbal, "Never Quite at Home: The Mystery of Fazlur Rahman's Anonymity in Pakistan," (A Graduate Thesis, Harvard University, March 2000)

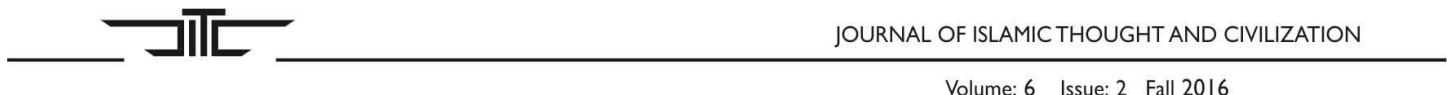


class English speaking intelligentsia of Pakistan, the name and work of Fazlur Rahman is rarely discussed or referred to. By and large this work addresses only the political aspect of the victimization of Fazlur Rahmanin Pakistan. ${ }^{65}$

Last but not least is The Shaping of an American Islamic Discourse: A Memorial to Fazlur Rahman. ${ }^{66}$ This is a memorial from the students to a dedicated teacher, showing his impact on his students who in turn are themselves working and impacting the way the discourse of Islam in America is taking shape; hence, it mainly deals with the last phaseof his life in the USA. This memorial contains twelve articles and an introduction on various subjects that Fazlur Rahman taught and published; for example works like Islamic Identity, Fazlur Rahman's response to Muhammad Iqbal, Fazlur Rahman and Islamic feminism, Muslim family law, Sufism, and Fazlur Rahman's contribution toreligious studies, to mention a few.

In the memorial's introduction, Earle $\mathrm{H}$. Waugh portrays a picture of the discourse taking place in America amongst the Muslims themselves and the academia in general about Islam and the impact, if any, of this discourse on the Muslim community of the world at large. Then, in the first chapter written by the same author, he attempts to place Fazlur Rahman's work in this large perspective. According to Waugh,

Both in his life and work, Rahman attempted to build bridges. He is also interesting because he was a vigorous conservative scholar within Sunni Islam who, nevertheless, both developed and ended his career in the West. Like many of his Muslim colleagues teaching at universities in the West, Fazlur Rahman had to face the difficulties encountered when trying to communicate to non-Muslim graduate students. He had to find ways of relating and opening young minds to the intellectual traditions of Islam while being aware of his students' background and intellectual environment. $^{67}$

Waugh believes that there are four principal areas of discourse to which Fazlur Rahman made significant contributions: the problematic interpretation of traditional sources; recovering Islamic philosophy; the nature of Islamic statehood; and modernizing Muslim Law. ${ }^{68}$ The content of the memorial largely revolves around these four principal areas to highlight Fazlur Rahman's contribution and impact on Islamic Studies in North America. Although there are numerous works on Fazlur Rahman-a comprehensive list is provided in the bibliography-to better understand Fazlur Rahman's thought evolution this book focuses on the works of Acikgenc and Denny since their works explore this aspect ingreater depth. While Denny mentions

\footnotetext{
${ }^{65}$ Ibid., 2.
}

${ }^{66}$ Earle H. Waugh, "Beyond Scylla and Kharybdis: Fazlur Rahman and Islamic Identity," in The Shaping of an American Islamic Discourse: A Memorial to Fazlur Rahman, (eds.) Earle H. Waugh and Fredrick M. Denny (Atlanta, Georgia: Scholars Press, 1998), 15-36.

${ }^{67}$ Ibid., 18-9.

${ }^{68}$ Ibid., 19.

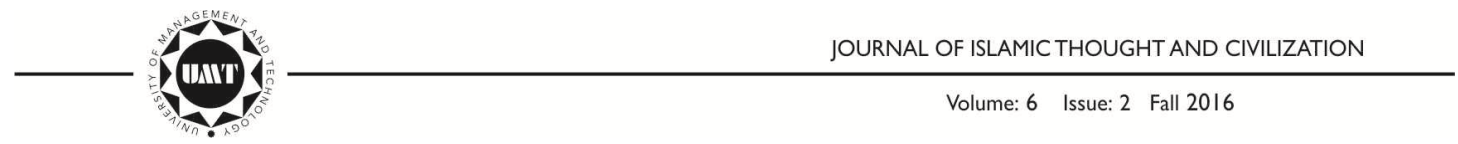




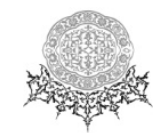

that he concentrates largely on Fazlur Rahman's academic phase in Chicago, as his work had matured by this period, he also finds itinteresting and worthwhile to trace his journey to this point. ${ }^{69}$ Acikgenc on the other hand openly admits, "I have tried rather to present his intellectual endeavour as a system of thought instead of exposing discrete solutions or ideas from his thought. Of course his response to these particular issues must be studied in order to be evaluated more effectively."70

\section{Conclusion}

The article focused on trying to place Fazlur Rahman's thought in perspective through the works of Islamicists who are accomplished and recognized in the world of scholarship on Islam. This survey revealed that some of the aspects of Fazlur Rahman's thought have exhaustively been covered, such as his methodology of Islamic modernism, while others, such as his intellectual role while he was in Pakistan, have been given very little attention. On the other hand some major aspects, such as the gradual evolution of his thought, have not been dealt upon in depth. A complete and synthetic work on Fazlur Rahman, focusing especially on the evolution in his thought needs to be carried out, because if the thoughts of a thinker's are studied the way they evolved with his life and times, a truer understanding of the working of his mind and a fuller grasp of his thought in motion can be understood and, thus, the different aspects of his thought can be better synthesized and given a proper shape. In Fazlur Rahman's case, such a study can make this extraordinary thinker relevant for the world today.

\section{BIBLIOGRAPHY}

Acikgenc, Alparslan. “The Thinker of Islamic Revival and Reform: Fazlur Rahman's Life and Thought (1919-1988)." In The Journal of Islamic Research. Vol.4, No.4 (1990): 232-48.

Berry, Donald Lee. "The Thought of Fazlur Rahman as an Islamic Response to Modernity." which was published as a book with the title Islam and Modernity through the Writings of Islamic Modernist Fazlur Rahman. Lewiston, N.Y: Edwin Mellen Press, 2003.

Cragg, Kenneth. "Fazlur Rahman of Karachi and Chicago." In The Pen and The Faith: Eight Modern Muslim Writers and the Qur'ān. London: George Allen \& Unwin, 1985.

Denny, Frederick M. “Fazlur Rahman: Muslim Intellectual.” In The Muslim World. Vol. LXXIX, No.2 (1989): 91-101.

\footnotetext{
${ }^{69}$ Fredrik Mathewson Denny, "Legacy of Fazlur Rahman," 98.

${ }^{70}$ Alparslan Acikgenc, "The Thinker of Islamic Revival and Reform: Fazlur Rahman's Life and Thought (1919-1988)," 274.
}

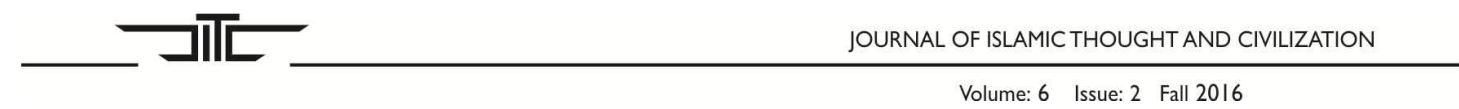


Denny, Fredrik Mathewson. "Legacy of Fazlur Rahman." In The Muslims of America, (ed.) Y. Y. Haddad. 96-108. New York: Oxford University Press, 1991.

Hussain, Waheed. "A Philosophical Critique of Fazlur Rahman's Islam and Modernity.” In Harvard Middle Eastern and Islamic-Review. Vol 6 (20002001): 53-81.

—. "Interpreting the Tradition: The Modernist Argument and the Source of Islam." In The American Journal of Islamic Social Science Vol.18, No.1 (2001): 1-15.

Iqbal, Aliya. "Never Quite at Home: The Mystery of Fazlur Rahman's Anonymity in Pakistan.” A Graduate Thesis. Harvard University, March 2000.

Jesse, Mary Catherine. "A Modern Muslim Intellectual: The Thought of Fazlur Rahman with Special Reference to Reason.” M.A Diss. University of Regina, 1991.

Manzoor, S. Parvez. "Damning History but Saving the Text: Fazlur Rahman between Tradition and Modernity." In Islamica, Vol. 2, no. 4 (1998)

Mohamed, Yasien. "Islamization of Knowledge: A Comparative Analysis of Faruqi and Rahman.” In Muslim Education Quarterly Vol. 11, No. 1 (1993): 27-40.

Ozdemir, Ibrahim. "The Concept of Islamic Tradition in Fazlur Rahman'sThought." In The American Journal of Islamic Social Sciences Vol. 9, No.2 (1992): 243261.

Panjwani, Farid. "Fazlur Rahman and the Search for Authentic Islamic Education: A Critical Appreciation.” In Curriculum Inquiry Vol.42, No.1 (2012): 33-55.

Rahman, Fazlur. Revival and Reform in Islam: A Study of Islamic Fundamentalism. (ed.) Ebrahim Moosa, Oxford: One world Publications, 2000.

Rahman, Fazlur. "Personal Statement." In The Courage of Conviction, ed. Phillip L. Berman, 153-159. New York, 1985,

Rasyid, Ahmar. "Some Qur'ānic Legal Texts in the Context of Fazlur Rahman's Hermeneutical Method." M.A Dissertation, Montreal: McGill University, 1994.

Shafiq, Muhammad. "Islamization of Knowledge: Philosophy and Methodology and Analysis of the Views and Ideas of Ismail Raji al-Faruqi, S. Hussein Nasr and Fazlur Rahman." in Hamdard Islamicus, Vol. XVIII, No.3 (1995): 63-75.

Sonn, Tamara. "Fazlur Rahman's Islamic Methodology." In The Muslim World, Vol. LXXXI, No.3-4 (1991):221-230.

Wan Daud, Wan Mohd Nor. "Islamization of Contemporary Knowledge: A Brief Comparison between al-Attas and Fazlur Rahman." In Al-Shajarah (Journal of the International Institute of Islamic Thought and Civilization). Vol. 2, No. 1 (1997): 253-61.

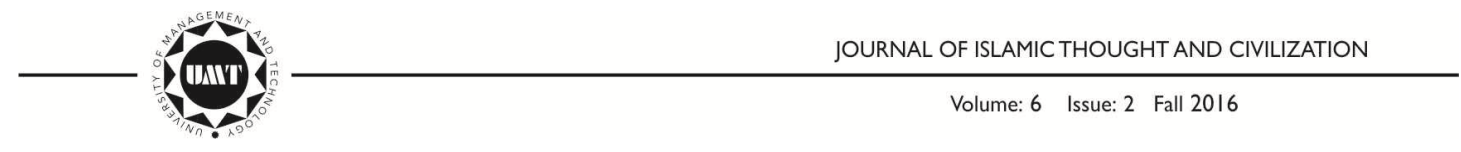


Waugh, Earle H., "Beyond Scylla and Kharybdis: Fazlur Rahman and Islamic Identity." In The Shaping of an American Islamic Discourse: A Memorial to Fazlur Rahman, (eds.) Earle H. Waugh and Fredrick M. Denny. Atlanta, Georgia: Scholars Press, 1998. 